УДК:7.027.2; 7.033.2

ББК: 85.13

DOI: $10.18688 / \mathrm{aa} 2111-02-22$

M. V.Cheimonopoulou

\title{
Palaeologan Veria: A Peripheral Center under the Perspective of Its Monuments. The Case of the Marble Decoration from the Old Metropolitan Cathedral as a Possible Donation by Christian Members of the Seljuk Dynasty
}

The restoration work carried out by the Ephorate of Antiquities of Imathia at the Old Metropolitan Cathedral in Veria has restored for the city its most important Byzantine church, a monumental palimpsest that recorded centuries of the history of the city and its people ${ }^{1}$.

The Middle Byzantine three-aisled basilica with transept was renovated by the Despots of Epirus and again during the era of the Palaiologan Dynasty. It was converted into a mosque around the turn of the $17^{\text {th }}$ century and remained Veria's great imperial mosque until the liberation of the city in 1912 [53, pp. 134-245, 265-271]. The first conservation and exploratory excavation work began in the 1960s [13, pp.249-250] and continued, albeit limited in scope and duration, until systematic restoration work on the monument eventually began (Ill. 32).

This essay presents sculptures that came to light during the first phase of the investigations and the main phase of the restoration of the Old Metropolis in 2011-2015. They form a group with common stylistic features and are associated with a phase of renewal of the church's liturgical furnishings in the first two decades of the $14^{\text {th }}$ century, when the ecclesiastical seat of Veria was raised from an Archdiocese to a Metropolitan seat [44, pp. 58-59].

The group of sculptures in question was first discovered in the period 1978-1980, when Professor Theocharis Pazaras, curator of antiquities of the newly founded $11^{\text {th }}$ Ephorate of Byzantine Antiquities, noticed characteristic groups of cornices, columns and slabs while arranging the collection of sculptures stored in the twin Ottoman bath [45, p. 161]. In the following years, the group was enriched thanks to the research work conducted by Professor Efthy-

\footnotetext{
For the recent restoration works, an account in G. Skiadaresis [53, pp. 254-257]. Main architectural study for the monument is the Ph.D thesis by G. Skiadaresis mentioned above [53]. For references of the monument in travelers' descriptions, general studies in Byzantine architecture, $\mathrm{Ph} . \mathrm{D}$ monographs and articles as well as ottoman document sources see: M. Delacoulonche [10, pp. 269-270], A. Struck, [58, pp. 32-33], Karpologou [22, pp. 280-281], Ch. I. Makaronas [28, p. 626], G. Chionidis [8, pp. 175-176], G. A. Sotēriou [56, pp. 568-569], G. M. Velenis [63, pp. 221-222], G. M. Velenis [64, pp. 49-59], N. Gioles [17, pp. 53-54], Ch. Bouras [6, pp. 113, 114, 117], F. A. Karagianni [21, pp. 74 (nt. 115, 116), 138, 158-159, 169, 191-192, 256-252], Sl. Ćurčič [9, pp. 395-396, fig. 430A], Th. Papazotos [44, pp. 83, 90-92, 164-169, 241-249, 250-253, 258-260, pls. 1-6, 8, 14, 33, 35-38], Th. Pazaras [47, pp. 251-254, pls. 136-147], Th. Papazotos [43, p. 200], E. H. Ayverdi [5, p. 233], and S. Eyice [14, p. 206].
} 
mios Tsigaridas on the later flooring of the Old Metropolis [45, pp. 161-162]. The work of the $1960-1980$ s added new finds to a distinctive group of Palaiologan sculptures of the $13^{\text {th }}-14^{\text {th }}$ centuries, which common characteristic is an oriental decoration of intertwined geometric and floral decorative motifs: circles, palms, pseudo-kufic characters, arabesques, with griffins, eagles, peacocks, and crosses. In his studies, Pazaras linked the finds with a Late-Byzantine pulpit in the double-staircase type with canopy [45, p. 162; 47]. The comparative study of these sculptures combined with information from the historical sources places the sculptures within a general tendency to renew the Islamic influences in Byzantine art during the Palaiologan period, but also permits the formulation of a working hypothesis possibly connecting them with the reported movements of members of the Seljuk dynastic house of the Sultans of Rum in Veria and its environs.

During the restoration work carried out on the monument between 2011 and 2015, the group of sculptures with oriental decoration was further enriched with finds that added new data. Removal of the floors in the north aisle revealed a marble panel, adjacent sections of a rectangular slab, and a triangular panel. These relief sculptures are adorned with oriental motifs whose closest parallels are found in the works of architectural sculpture and miniature arts of the Seljuk Islamic Sultanate of Rum in Anatolia ${ }^{2}$. The intact panel (Fig. 1), measuring 1,01 by 0,855 by $0,07 \mathrm{~m}$, retains relief decoration only on its upper half. Its central subject is a pair of circular motifs inscribed within quadrilateral frames; interlocking triangles within the circles form six-pointed stars, lance-like patterns and hexagonal rosettes. The thickness of the panel is $7 \mathrm{~cm}$, which is similar to that of the Middle-Byzantine panels of the church and to the width of the groove on the stylobate of the sanctuary screen for the panels of the iconostasis (Figs. 2-4). This similarity may indicate that it was installed as a completion or repair in the Palaiologan period, while the other dimensions are associated with heights of 0.90 to $1 \mathrm{~m}$ and a width of 0,85 to $0,87 \mathrm{~m}$.

Similar interlocking and emerging circular motifs within square frames, which in turn enclose knots, adorn the adjacent parts of another panel to which, in accordance with the surviving finds, belong fragments with similar decoration executed in a drilling technique (Fig. 5).

The work also brought to light part of a triangular marble slab formed of three attached parts and several smaller ones, similar to a triangular slab published by Pazaras [45, p. 161, fig. 31; 47, pl. 137 7]. The champlevé decoration of this panel forms a continuous naturalistic scroll of tendrils, which include stems and leaves, and is stylistically similar to a rectangular slab discovered during the first phase of work on the monument (Fig. 6).

The following sculptures come from the initial phase of investigation:

1) Cornices and epistyles with a concave façade adorned by a continuous grid of interlocking diagonal bands (like basket-weave) ${ }^{3}$ [45, pp. 161, fig. 28a-b, 29a-c, 34d; 47, p. 252, pls. 136-147] form three groups of fragments that might belong to tapering

2 For similar ornaments and patterns, see E. B. Marangoz [29, pp. 88, 92, 97, 122, 151, 210, 211, 252, 257, 270, 271, 296, fig. 75, 80, 85, 105, 144, 195, plans 20, 31, 33, 38, 39], K. Özkul [41], and K. Özkul [42, fig. 2, 15]. For an elaborate arabesque on a $12^{\text {th }}$-century wood panel from Egypt, see R. S. Nelson [36, p. 159, fig. 19].

3 Pazaras mentions traces measuring $0,38 \times 0,38 \mathrm{~m}$ on the underneath surface of one of them for the adjustment of the four capitals mentioned in the number 3) of the description [47, p. 252, pls. 136-147]. 

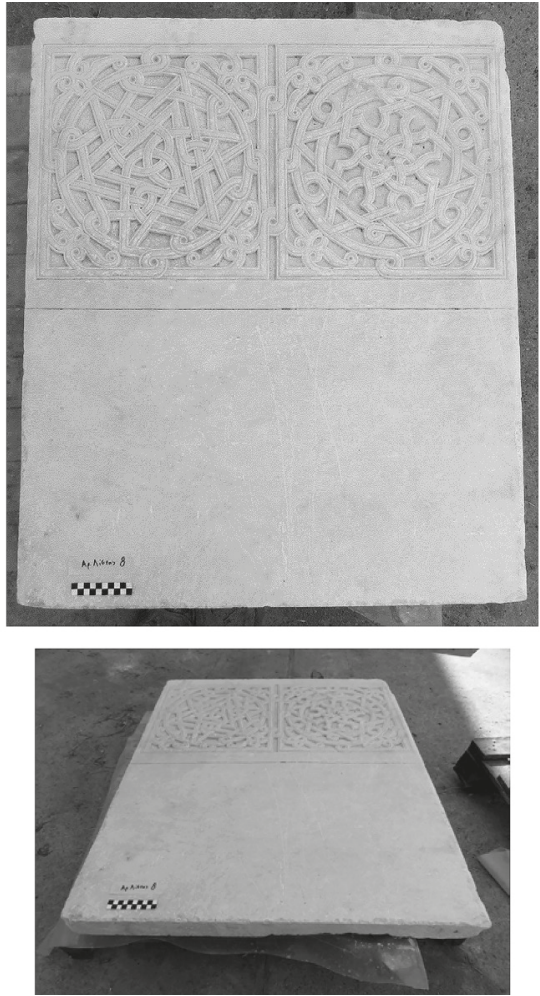

Fig. 1. Veria, Old Metropolitan Cathedral. Panel (no ПМВ/2015/2978). Hellenic

Ministry of Culture and Sports, Photographic Archive of the Ephorate of Antiquities of Imathia

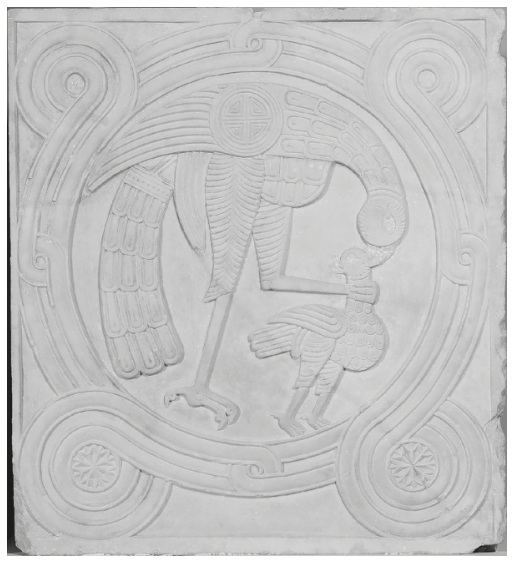

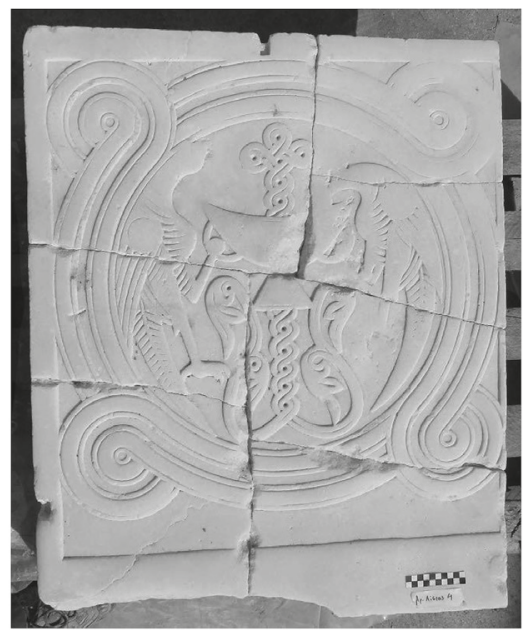

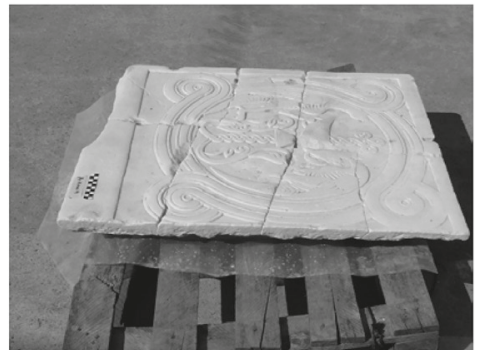

Fig. 2. Veria, Old Metropolitan Cathedral. Panel of the sanctuary screen. Hellenic Ministry of Culture and Sports, Photographic Archive of the Ephorate of Antiquities of Imathia

Fig. 3. Veria, Old Metropolitan Cathedral. Panel of the sanctuary screen (Birds). Hellenic Ministry of Culture and Sports, Photographic Archive of the Ephorate of Antiquities of Imathia 

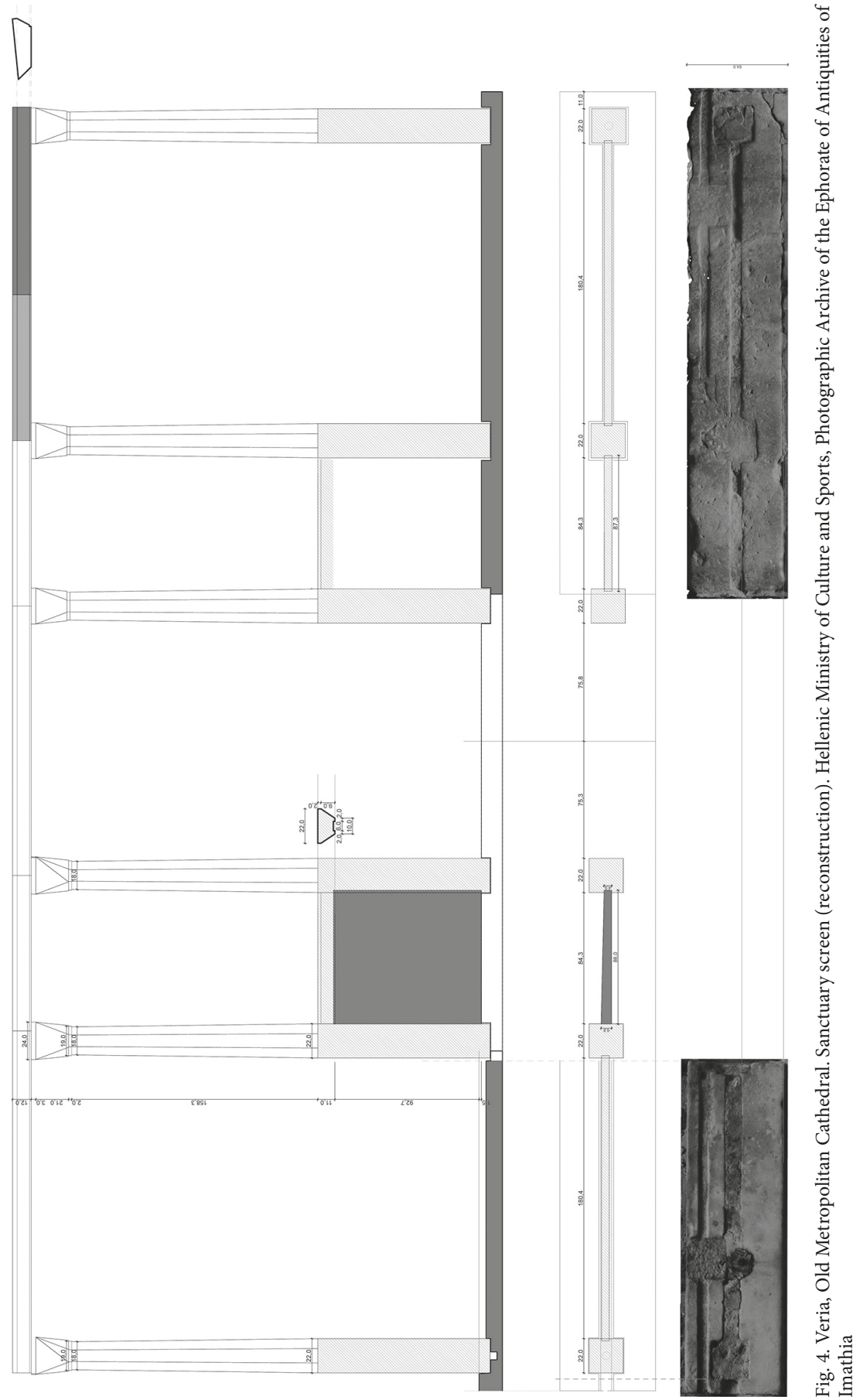


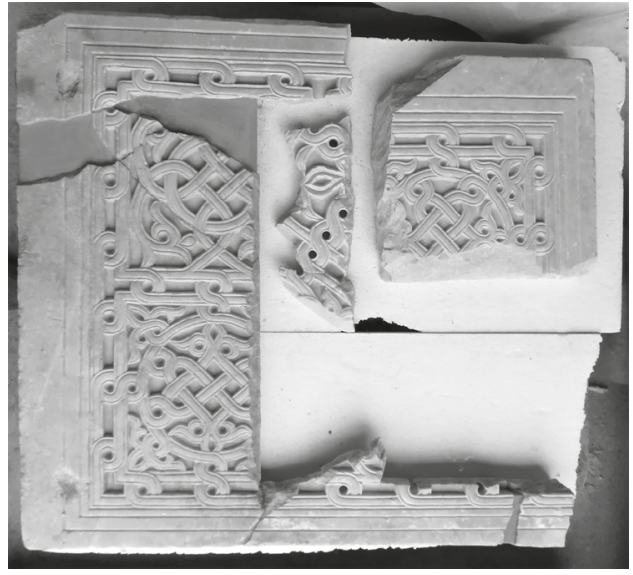

Fig. 5. Veria, Old Metropolitan Cathedral. Panel (no $\Pi \mathrm{MB} / 2013 / 1572$ ). Hellenic Ministry of Culture and Sports, Photographic Archive of the Ephorate of Antiquities of Imathia

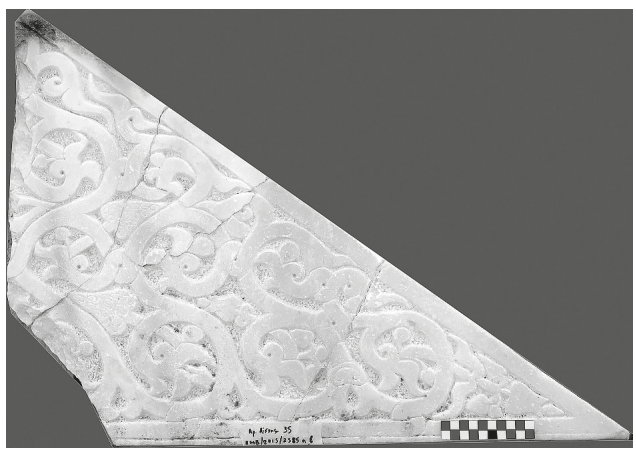

Fig. 6. Veria, Old Metropolitan Cathedral. Triangular slab (no ПMВ/2015/2585). Hellenic Ministry of Culture and Sports, Photographic Archive of the Ephorate of Antiquities of Imathia

epistyles or claddings, decreasing in size from 0,43 to $0,35 \mathrm{~m}, 0,40$ to $0,30 \mathrm{~m}$ and $0,34-0,33$ to $0,25-0,26 \mathrm{~m}$ (Fig. 7). Similar marble fragments/reliefs adorned the cornices of the until recently preserved Ottoman minbar of Aghia Sophia in Ochrid [33, p. 146, fig. 156; 32, fig. 38] and some lintels from the katholikon of the Chilandari Monastery [33, p. 146, fig. 154-155], while the decorative pattern of a triple line of thin strands is also found in the decoration crowning a panel in Aghia Sophia in Ochrid [18, Pl. CXXXIXb], in the frame of a fragmentary panel from the church of the Dormition of the Virgin in Makrinitsa, Pelion [18, Pl. CXXXIXd], and in the late $13^{\text {th }}$ /early $14^{\text {th }}$-century ciborium from the southern imperial ecclesiastical foundation of the Lips Monastery in Constantinople dedicated to John the Baptist [27, fig. 63]. The later, $14^{\text {th }}$-century, examples of this strand motif are traced in the relief cornices on Serbian church facades in the Morava Valley, such as the church of the Dormition of the Virgin in the Ljubostina Monastery [9, p. 681, fig. 793].

2) Chamfered cornices (Fig. 8) share a common decorative theme of continuous interlocking vegetal bands, which include floral arabesques made from interlocking stems [45, p. 161, fig. 26-27; 47, pls. 136 1 ]. In one of the cornices a medallion with an encircled monogram read as Demetrios is preserved [45, fig. 27; 47, pls. $136_{2 \gamma}, 147_{23}$ ]. The decorative themes are executed in the champlevé technique and low relief. It is noteworthy that both techniques, separated by a plain section, are preserved in one of the cornices, a detail that supports the hypothesis that these fragments are all part of a single set. In this group of reliefs, several of which are attached, most of their decoration is executed in champlevé, with the decorative motif highlighted by a background 

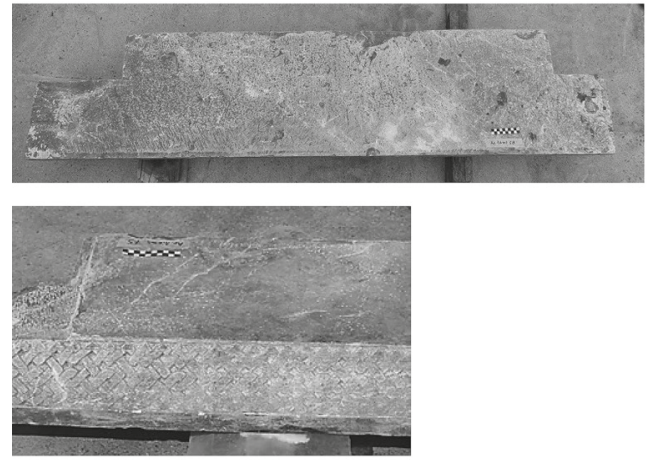

L. 2,07 m, W. 0,28-0,45 m, H.: 0,11 m
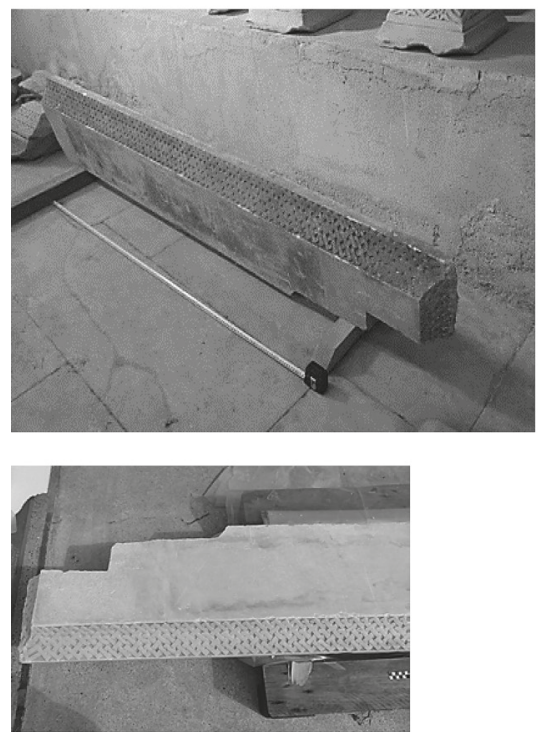

L: 2,30 m, W (under) : 0,30 m W. (upper): 0,40 m, H: 0,11 m

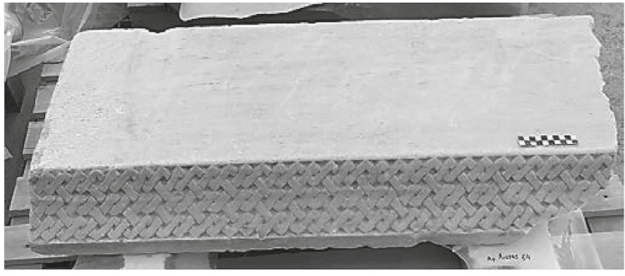

L. : 1,03 m, W. (under): 0,35, W. (upper: 0,43 m, H.: 0,12 m

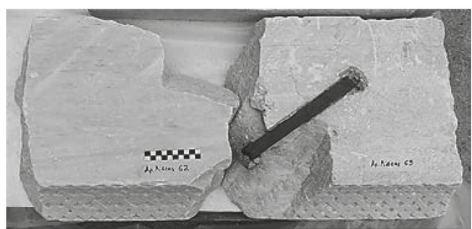

L. : 0,78 m, W. (under): 0,35 m,

W. (upper). : 0,43 m, H: 0,115 m

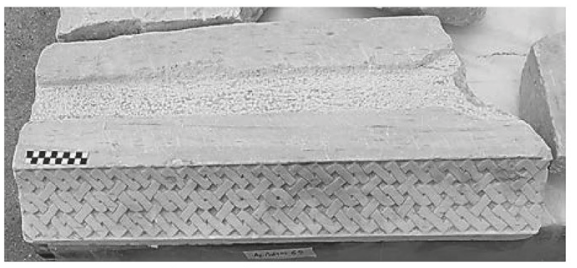

L.: 0,82 m, W. (under): 0,255 m,

W. (upper): 0,33 m, H.: 0,11 m

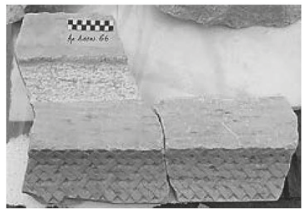

L. : 0,60 m, W (under): 0,26 m,

W. (upper): 0,34 m, H.: 0,115 m

Fig. 7. Veria, Old Metropolitan Cathedral. Cornices and epistyles (nos 1369/Г305, 615/Г202, 613/Г47, 1369/Г221, 612/Г46). Hellenic Ministry of Culture and Sports, Photographic Archive of the Ephorate of Antiquities of Imathia

infill of black inlay ${ }^{4}$. Where low relief is used, the vegetal band is rendered with double curved outlines and the recessed field remains plain. Reliefs of similar decoration can be seen at the Church of Aghia Sophia in Ochrid [45, pp. 161, 166, fig. 5a-c], the katholikon of the Chilandari Monastery [38, pp.108, 110, fig. 18, 20], the Church of Episkopi, Ano Volos [1, fig. 5, p. 536], the Church of Aghios Ioannis Prodromos

4 The use of the technique results in a painterly rendering. For an iconographical example see R. S. Nelson [37, fig. 7]. 

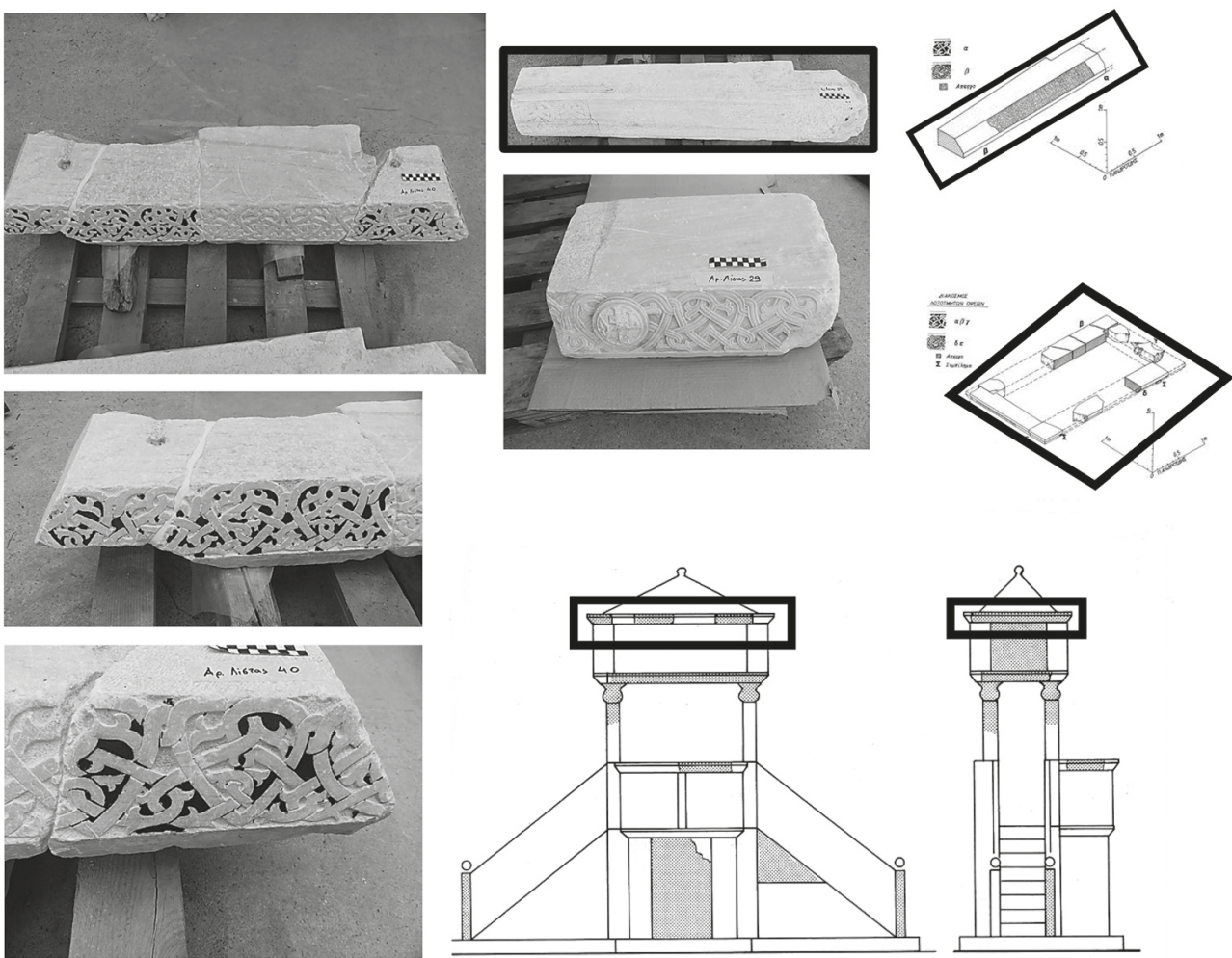

Fig. 8. Veria, Old Metropolitan Cathedral. Cornices (nos 620/Г59, 622/Г52, 623/Г53, 624/Г54, 1369/Г252, 1546/Г506). Hellenic Ministry of Culture and Sports, Photographic Archive of the Ephorate of Antiquities of Imathia
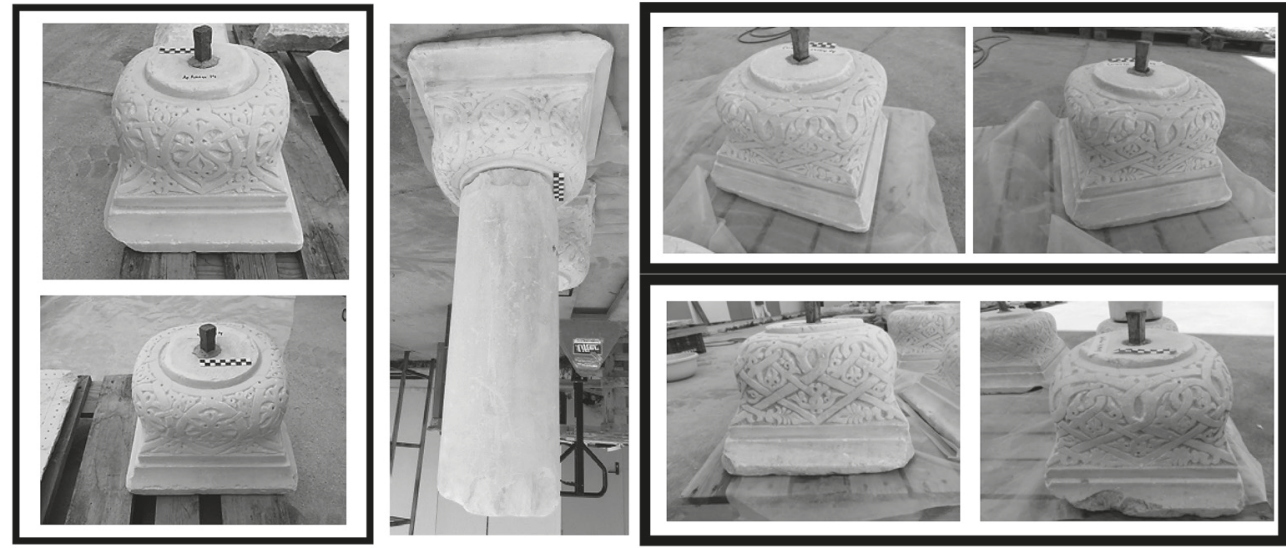

Fig. 9. Veria, Old Metropolitan Cathedral. Two pairs of cauldron-shaped capitals (nos 551/Г2, 552/Г3, 553/Г4). Hellenic Ministry of Culture and Sports, Photographic Archive of the Ephorate of Antiquities of Imathia 
in Portaria, Pelion [30, p. 38, fig. 41-42], the katholikon of the monastery of Aghios Lavrentios in Pelion [16, p. 390, fig. 4-5; 25, pp. 242-244, pl. 97a- $\beta$ ], and the Byzantine and Christian Museum in Athens [11, pp.278, 280, 281, fig. 1-5]. In his proposed reconstruction of the pulpit, Pazaras related and graphically restored these sculptures as a chamfered cornice placed below the four-sided roof of the pulpit's canopy, measuring approximately $2,50 \times 1,40 \mathrm{~m}\left[47\right.$, p. 253 , pls. $\left.142_{14}, 145_{19}\right]$.

3) Two pairs of cauldron-shaped capitals (Fig. 9) [45, fig. 30a-d; 47, p.251, pl. 1376a- $\delta$ : the body of the first pair is covered with low-relief decoration consisting of narrow interlaced bands that form lozenge-shaped panels incorporating diminutive, crosshatched, blossoming vine scrolls or inverted larger buds in heart-shaped frames. The triangular forms of the upper part of the body, beneath the entablature, are decorated with flowers bearing lance-like petals. The body of the second pair of capitals is covered with low-relief decoration consisting of a narrow, interlaced band forming elliptical pointed panels that frame inverted and fragmented blossoms. Cross-hatched buds decorate the space between the panels. The pairs of capitals present many stylistic similarities to the ones from the pulpit of Aghia Sophia in Ochrid, dated to 1317 [18, pp. 149-150, Pl. CXXXVIIIa-c].

4) A triangular slab bearing a double foliate cross with interlaced vine scrolls [45, p. 161, fig. 31; 47, p. 251, pl. 1377] presents a system of organising and executing the theme of foliate crosses similar to those on the capitals of the window mullions in the sanctuary of the katholikon of the Chilandari Monastery [38, pp. 86, 118, 122, fig. 30, 34, $35,107]$.

5) Two quadrilateral slabs preserve intersecting circles, palmettes and half palmettes surrounded on three sides by a guilloche (Fig. 10). In the representation of the pulpit proposed by Pazaras, they are placed on the narrow sides of the canopy [45, p. 162, fig. 33; 47, p. 251, pls. $\left.138_{8 \alpha-\beta}, 142_{14}\right]$. Similar rosettes of arabesque influence are preserved on the canopy sides of the Ottoman pulpit of Aghia Sophia in Ochrid [18, pp. 149-150, Pl. CXXXVIa; 32, fig. 38], on a marble slab from the katholikon of the monastery of Aghios Lavrentios in Pelion [4, pp.460-461, fig. 11], on the panels of the bishopric of Ano Volos [2, fig. 1-2, 4; 3, p. 93, fig. 13] $]^{5}$, while the chronologically later ones decorated the monumental facades of the Morava valley churches in the $14^{\text {th }}-15^{\text {th }}$ centuries 6 [ 7 , p. 334, fig. 1$]$.

\footnotetext{
We also note a similar rosette from an immured panel in a façade of St. Sophia in Trebizond (drawing in P. Androudis [2, p. 164, fig. 6b].

6 Besides Kalenić, the following monuments are mentioned: St. George at Pološko, St. Archangel Michael at Lesnovo, Marko's monastery near Skopje, Holy Archangels in Kučevište, St. Nicholas in Ljuboten, St. Nicholas Šiševski on Treska, Matejić monastery, and St. Andrew monastery at Matka.
} 

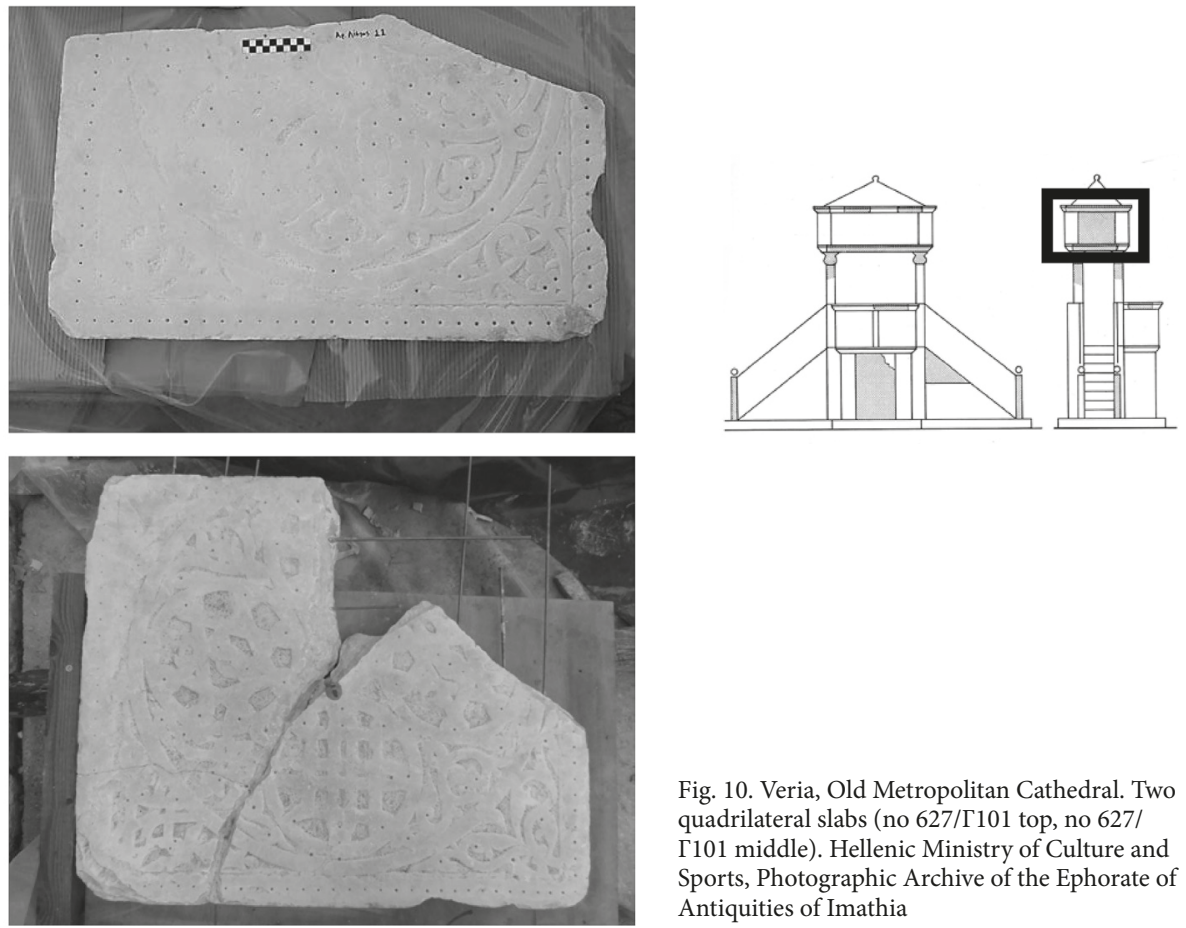

Fig. 10. Veria, Old Metropolitan Cathedral. Two quadrilateral slabs (no 627/Г101 top, no 627/ $\Gamma 101$ middle). Hellenic Ministry of Culture and Sports, Photographic Archive of the Ephorate of Antiquities of Imathia
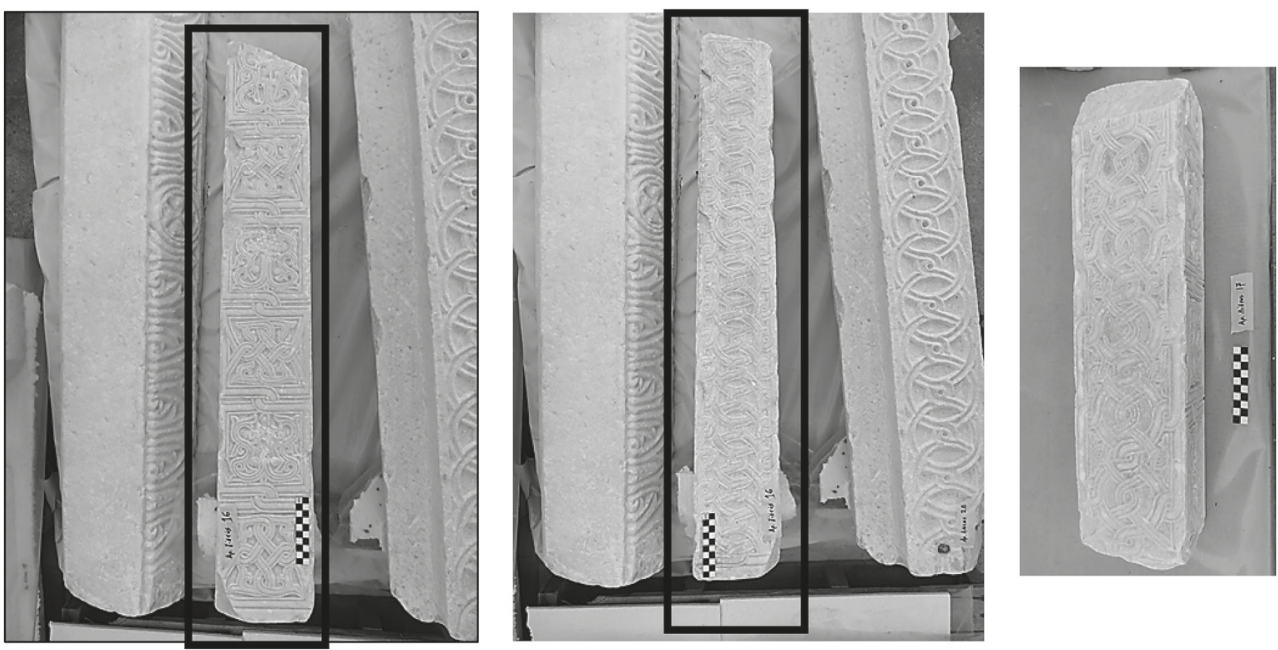

Fig. 11. Veria, Old Metropolitan Cathedral. Pair of colonnettes (no 597/Г41). Hellenic Ministry of Culture and Sports, Photographic Archive of the Ephorate of Antiquities of Imathia 
6) Two colonnettes (Fig. 11) [45, p. 162, fig. 34ab; 47, p. 251 , pl. $138_{9 \alpha-\beta}$, each of which has two adjoining faces bearing relief decoration, are adorned with intersecting circles and foliate ornaments of interlaced leaf crosses identical to those on the colonnettes from the Ochrid pulpit [45, p. 165, fig. 4a-b].

7) A rectangular slab with part of its upper right corner missing retains, on its left side, a pointed arch framing quadrilateral compartments [47, p. 252, pl. 13910]. The lower half of the slab is decorated with a composite arabesque of a cruciform central rosette inscribed within a circle, which in turn is framed by a square. The corners of the square are occupied by five-petalled palmettes (Fig. 12).

This particular style of sculpture was first pointed out by Gabriel Millet [33, p.146, fig. 154-156], who observed the similarities between the Ottoman pulpit (minbar) in Aghia Sophia in Ochrid adapted from parts of a Byzantine pulpit and the canopy/ciborium known as the throne of Archbishop Gregorios

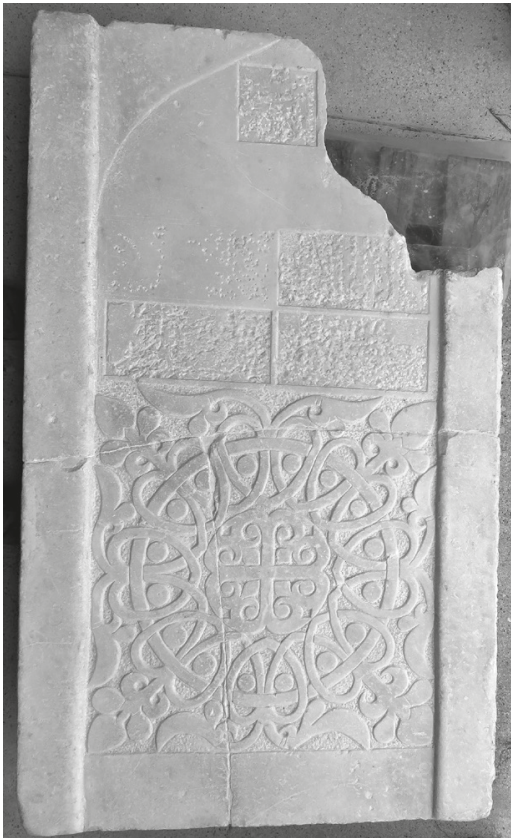

Fig. 12. Veria, Old Metropolitan Cathedral. Slab (no 1369/Г297). Hellenic Ministry of Culture and Sports, Photographic Archive of the Ephorate of Antiquities of Imathia of Ochrid, the epistyle of the templon barrier in the Church of Porta Panaghia [24, p. 74, fig. 141; 40, pp. 27-29], the lintels in the katholikon of the Chilandari Monastery, the façade and sides of the sarcophagus of Anna Maliassene and a pediment slab with foliate ornamentation, all from the church of Episkopi, Ano Volos. Millet also connected the tombstone of Anna Maliassene's husband, Nicholaos, with the sculptures from Episkopi, Ano Volos [33, p. 146]. George Sotiriou was the next scholar to discuss the stylistic connection between these works of sculpture [57, pp.78-81], and André Grabar added to this group the sarcophagus of George Kapandritis from Thessaloniki ${ }^{7}$ [18, p. 151, Pl. CXXXIIIa-b]. Later on, the group was further enriched, with the addition of relief sculptures from the katholikon of the Chilandari Monastery, namely the lintels over the western entrance to the inner narthex and the doorway between the inner narthex and the nave, the capitals of the window mullions in the sanctuary, and the marble slabs beneath the windows of the northern choir ${ }^{8}$ [38, p. 108, fig. 20, 34-35, 107, 128], epistyles from the Byzantine and Christian Museum [11, pp. 278, 280, 281, fig. 1-5], and similarly decorated sculptures from the monastery of Panaghia and Aghios Dimitrios near Tsagezi [55, p.368, fig. 21], the churches of Taxiarchis in Locris [39, pp.367-368, fig. 20; 59], Aghios Lavrentios in Pelion [16, p.390, fig. 4-5; 26, pp. 242-244,

See also the study by A. Xyngopoulos [66].

Also P. Mylonas [35]. 
pl. 97a- $\beta$ ], Aghios Athanasios in Makrinitsa [1, p.535, fig. 1] and the Dormition of the Virgin at Oropos [23, p. 82, no. 55, pl. 40a], the archaeological collection in the Chalkida mosque [46, p. 50, no. 68, pl. 55ß], and the archaeological site of Mistras [32, pp. 203, 254, fig. 75].

The similarities between the marble reliefs from the Old Cathedral and parts of the Ottoman minbar of Aghia Sophia in Ochrid, attributed by Petrov to a reconstructed Late-Byzantine pulpit in the double staircase with canopy type [48], led Pazaras to correlate these sculptures with a marble pulpit and reconstruct it in a way similar to that of Aghia Sophia in Ochrid. Although Pazaras concedes that there are several pieces missing from this reconstruction, he considers it realistic in general. His scientific contribution lies in the fact that he has identified a previously unknown piece of Late-Byzantine liturgical furniture from the Old Cathedral of Veria by taking into consideration the reconstruction of a Late-Byzantine ambo in Ochrid, corner elements in the surviving cornices and epistyles from the Old Metropolis, and Adolph Struck's information about the existence of an Ottoman minbar in the Old Metropolis mosque [58, p. 32]. Pazaras dated the proposed reconstructed pulpit of Veria to the period around 1300, along with the doors and windows from the katholikon of the Chilandari Monastery and the pulpit of Aghia Sophia in Ochrid, and more specifically to the period 1300-1317, as part of a further renovation of the Old Cathedral. He also associated the medallion framing the monogram Demetrios inscribed on one of the cornices with a bishop of Veria, unknown from written sources, from the period 1285-1326 when there was a gap in the Episcopal catalogue [47, pp. 253-254].

Recent work on the floors of the north aisle of the Old Metropolis also brought to light a marble slab, $10 \mathrm{~cm}$ thick, which retains part of a circle marked by a groove and traces of mortises/sockets on its upper surface, which could have come from the platform of a pulpit. A sculpture that resembles part of an unfluted column was discovered during the work carried out in the south part of the narthex. It partially preserves a groove for support on one end, and could therefore be combined with the above pulpit platform, forming part of its infrastructure. To these elements, one may possibly add a fragmentary Middle-Byzantine slab from the earlier excavations. This slab, 9-10 cm thick, might belong to a staircase parapet, and with the two previous fragments compose a pulpit exemplifying the ellipsoid, double-staircase plan typical of the Middle Byzantine phases of the monument ${ }^{9}$ (Fig. 13).

After the restoration of the marble sculptures with oriental decoration, and especially after the work on the chamfered cornice with continuous heart-shaped motifs, different elements have been discovered relating to the proposed plan of reconstructing these parts as a cornice from the canopy of a pulpit/ambo. In particular, certain basic variations are found, as four segments with champlevé decoration form the integral sides of a structure and not the proposed part of one of the canopy's long sides (Ill. 33, green indication). Also, three pieces that have been placed: one on one of the long sides of the quadrilateral cornice, and two others that had been placed on one of the narrow sides of the cornice, are joined together, breaking the proposed original scheme (Ill. 33, orange indication). Finally, parts of the proposed integral narrow side are not joined together (Ill. 34). While measuring the dimensions of the architrave, which according to the proposed reconstruction is supported by the four capitals,

9 Of similar type, like the one from the church of Durmuş Kadir Kilise in Cappadocia, see M.Dennert [12, taf. 50,3]. 

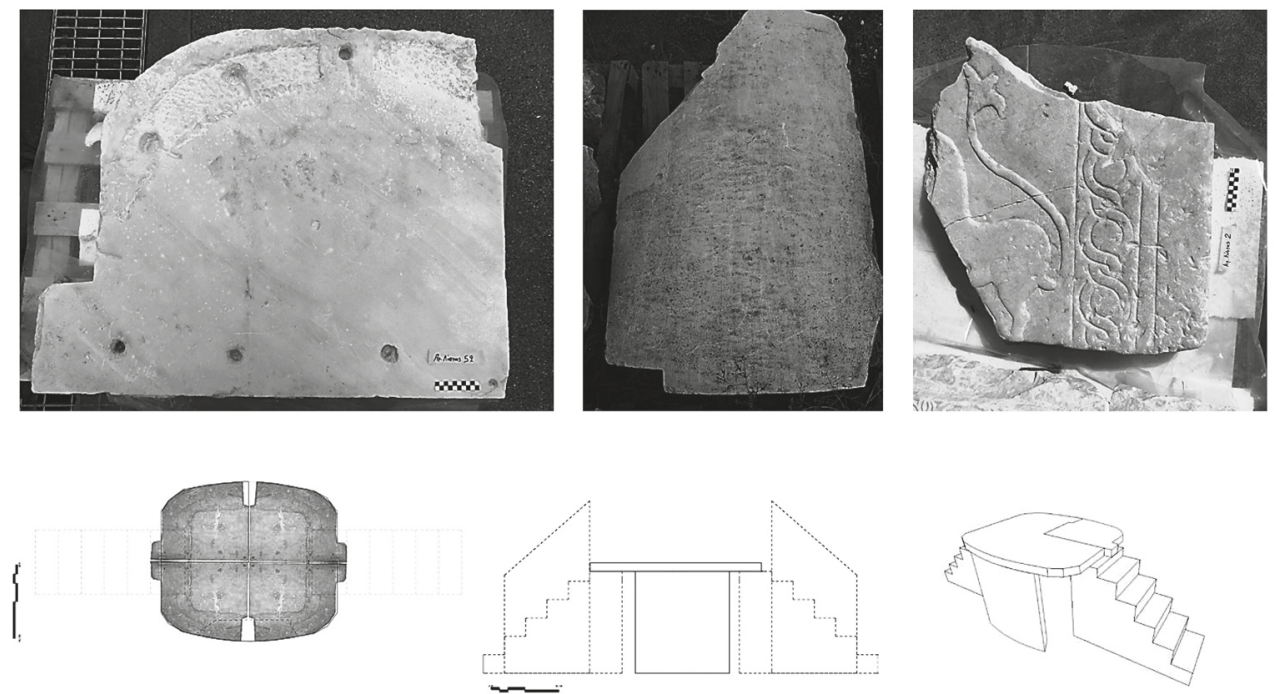

Fig. 13. Veria, Old Metropolitan Cathedral. Left, slab possibly from an ambo platform (no ПМВ/2013/1991). Middle, part of a column and right part of a parapet. Bottom, possible reconstruction of a pulpit out of basic elements (Plans by M. Chatzimichali, Architect / masters degree). Hellenic Ministry of Culture and Sports, Photographic Archive of the Ephorate of Antiquities of Imathia

it was found that the capitals are $7 \mathrm{~cm}$ wider than the supposed architrave. Excavation data have also provided information on the possible location of the Christian pulpit, in the middle of the central aisle, and the excavation of two Ottoman minbars have identified their position on the opposite axis, in contact with the south wall of the building in the Ottoman period. If these elements were correlated to the parts of the pulpit platform and infrastructure that can be ascribed to a type of ellipsoid plan, it is quite possible that the pulpit of the monument belonged to the type with two staircases but without the proposed canopy plan (Ill. 35, yellow indication).

The above elements, combined with the dimensions of the panel with the double oriental motif, which approach those of the Middle-Byzantine panels of the monument, and the proportionally reduced thickness of the $14^{\text {th }}$-century triangular slabs, just $0,04 \mathrm{~m}$ for members usually $0,10 \mathrm{~m}$ thick, are indicative of a renewal of the sculptural decoration of the church at the time of the raising of the church to a Metropolitan seat (Ill. 35, purple indication). This renewal could comprise partial completions and modifications of the Middle Byzantine elements in the pulpit, as in the case of the triangular slabs, the templon barriers, as indicated by the panel with oriental decoration, and other liturgical installations and settings as well, for which elements are no longer preserved due to the constant transformations and repairs of the building.

To the Palaiologan sculptures with oriental decoration from the Old Cathedral may also be added fragments from funerary monuments with similar decoration that have been discovered in Veria, mainly from church floors. These are a tombstone with monograms once embedded 


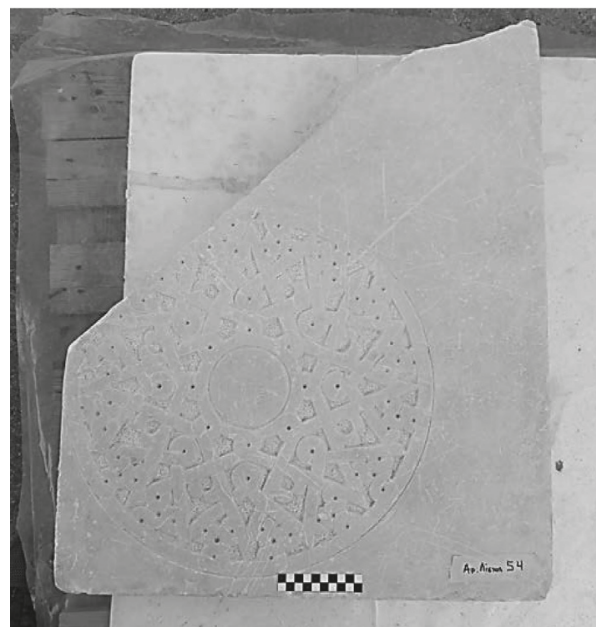

Fig. 14. Slab from the Ephorate's sculptures collection. Hellenic Ministry of Culture and Sports, Photographic Archive of the Ephorate of Antiquities of Imathia

in the floor of the church of Panaghia Pantanassa or Paleophoritissa ${ }^{10}$ and a marble slab, probably part of a larger piece, which preserves a circular arabesque ornament (Fig. 14), very similar to that on the slab of Maliassenos [1, fig. 1, p. 535].

Comparable Islamic ornaments are also found in a series of Palaiologan manuscripts. Here, the arabesque motifs are equally influenced by Komnenian tradition and the transfer of Anatolian Seljuk motifs through artistic creation from Iconium to Constantinople. The constant communication between the worlds of Byzantium and Anatolia, detectable in art, reflects the political and social realities that shaped the Komnenian and Palaiologan eras ${ }^{11}$.

One may, consequently, wonder whether, in the context of these exchanges and communications between the Byzantines and the Seljuks, the Palaiologan sculptures of the old Cathedral might not in fact be associated with the presence, documented by written sources, of the family of Sultan 'Izz ad-Din Kaykaus II of Iconium in Veria?

According to written sources, members of the family of the sultan 'Izz ad-Din Kaykaus II, his mother, attested as Greek by both Christian and Muslim writers ${ }^{12}$ [52, pp. 106, 109], possibly his wife, and various noblemen remained settled in the Byzantine regions of Veria, the Giannitsa marshlands and Zechne, in Serres [65; 25; 67; 51, pp. 180-190; 52, pp. 99-131, 157-215]. The districts in the region of Veria of Komanitzes, Tourkochori-Patrida, and the areas of Meliki, Ressiane, and Nese, which were traditionally known in Greek by the name of Roumlouki, are mentioned in the documents as concessions to the noble incomers [60], that is, the members of the dynast's family and supreme officials of the Seljuk ruling house, most of them Greekspeaking Christians ${ }^{13}$ who considered themselves to be Rumi. Those named were Prodoulia, Melik Constantine, Theodora Soultanina (Veria, PLP, no. 26335), Xene Soultanina Palaiologina

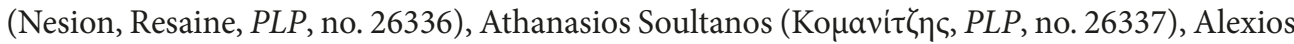
Soultanos Palaiologos (Nesion, PLP, no. 26338), Demetrios Soultanos Palaiologos (Resaine, PLP, no. 26340) and Soultanos Palaiologos (Veria, PLP, no. 26341). The settlement of Rumi

10 Two researchers propose different readings for the epigraph: Pazaras reads $\triangle$ IAKONOY K $\Lambda$ HMENTO $\Sigma$ (of Clement the deacon) [46, p. 26, no. 13] and Papazotos reads $\triangle$ OYKAN $\Lambda$ HZIKON ( $\triangle$ OYKAN $\Lambda$ YIKON, duke Lyzikos) [44, p. 103].

11 See [36], with references to sources documenting the presence of Islamic ornamental art in objects and buildings during the twelfth and thirteenth centuries.

12 See George Pachymerēs [15, vols. I-II, I, 131, 2] and Nikēphoros Grēgoras [62, vols. I-IV, IV, 94, 13-14].

13 See Georges Pachymerēs [15, vols. I-II, II, $\$ 612,13-16$, and $₫ 613$, 7; and vol. III, XIII, $₫ 675,2-14]$ : $\delta$

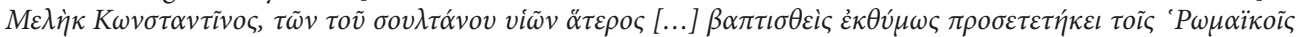
$\ddot{\eta} \theta \varepsilon \sigma \iota v$. 
sultans in the Veria district probably contributed to the region's later appellation of Roumlouki, that is perhaps, the place of those who came from Anatolia and called themselves Rumi ${ }^{14}$.

Since we know from the archival researches of E. Gara that the Old Metropolis of Veria and its environs were known in the late $16^{\text {th }}$ and early $17^{\text {th }}$ century as the Melek Monastery [54, p. 542, footnote 25], we think it probable that the architectural sculptures described above were given to the church by that family, who could, in general, have been its patrons and benefactors. The subject matter of the sculptures, although widespread in the Palaiologan era as the result of the interaction of the Christian with the Islamic world, indicates a partiality on the part of the sponsors for this type of decoration.

The above made hypothesis that the Palaiologan sculptures of the Old Cathedral might be associated with the settlement of Christian members of the Seljuk Dynasty in Veria and its environs offers also a realistic possibility for the preference of this particular type of Islamic decoration rather than only perceiving it within the decorative tendencies of the time.

\section{References}

1. Anastasiadou A.; Kontogianopoulou M. The Burial Epigram of a Palaiologue at Makrinitsa in Pelion and Its Relation with the Burial Monuments of the Maliassinoi in Magnesia. Archaiologiko Ergo Thessalias kai Stereas Elladas 2, Praktika epistēmonikes synantēseis 16.3-19.3.2006, vol.1: Thessalia. Volos, University of Thessaly and Ministry of Culture Publ., 2009, pp. 525-537 (in Greek).

2. Androudis P. Sur les fragments d' une chaire épiscopale byzantine à Episkopi (Anô Volos). Byzantiaka, 2002, vol.22, pp. 143-168 (in French).

3. Androudis P. The Church of the Dormition of Virgin at Episkopi Ano Volos and Its Immured Sculptural Decoration. Deltion tēs Chistianikēs Archaiologikēs Etaireias, 2007, vol. 28, pp. 85-98 (in Greek).

4. Androudis P. Byzantine Sculptures from the Katholiko of St. Laurentius Monastery in Pelion. Archaiologiko ergo stē Thessalia kai Sterea Ellada 4, Praktika epistēmonikes synantēseis, Volos, 15.3 - 18.3.2012, vol. 1: Thessalia. Volos, University of Thessaly and Ministry of Culture Publ., 2012, pp. 457-468 (in Greek).

5. Ayverdi E. H. Avrupa'da Osmanlı Mimari Eserleri, Bulgaristan, Yunanistan, Arnavutluk, vol. 4 (4.,5., 6. kitap). Istanbul, Fetih Cemiyeti Publ., 1982. 508 p. (in Turkish).

6. Bouras Ch. Byzantinē kai Metabyzantinē Architektonikē stēn Ellada. Athens, Melissa Publ. 2001. 314 p. (in Greek)

7. Bozinovic V. Rosettes on the Monuments of Morava Serbia and Early Ottoman Bursa: Architectural Decoration as a Manifestation of Intercultural Dialogue during One Epoch, International Scientific Symposium, Niš and Byzantium 16 (2018), pp.333-342.

8. Chionidis G. Historia tēs Verias II. Thessaloniki, s.e., 1970. 246 p. (in Greek).

9. Ćurčić Sl. Architecture in the Balkans from Diocletian to Süleyman the Magnificent, c. 300-1550. New Haven, Conn., Yale University Press, 2010. 913 p.

10. Delacoulonche M. Missions scientifiques et litteraires: Memoire adressé a son exc. le ministre de l' instruction publique et des cultes sur le berceau de la puissance Macédonienne, des bords de l' Haliacmon á ceux de l' Axius. Paris, Imprimérie et Librairie Administratives de Paul Dupont, 1858. 288 p. (in French).

11. Demetrakopoulou-Skylogianni N. Four Champleve Late Byzantine Sculptures from the Byzantine Museum. Deltion tēs Christianikes Arghaiologikēs Etaireias, 1991-1992, vol. 16, pp. 277-282 (in Greek).

12. Dennert M. Mittelbyzantinische Ambone in Kleinasien. Istanbuler Mitteilungen, 1995, vol.45, pp.137147 (in German).

14 For the various aspects and meanings of the word Rum and Rumi see A. G. Savvidēs [49, pp. 95-102], also C. Kafadar [20, pp.7-25]. For the prevailing view on the etymology and therefore reasoning of the areass name as Roumlouki in the regional bibliography meaning the land of Greeks, see N. Shinas [50, vol.1-2, pp. 176, 203-207], G. Melikis [31, p. 63] and G. D. Moschopoulos [34, p. 13]. 
13. Drossogianni F. Palaia Metropolis. Archaiologikon Deltion, 1963, vol. 18/2, pp. 249-250 (in Greek).

14. Eyice S. Yunanistan'da Türk Mimari Eserleri. Türkiyat Mescmuasi, 1955, vol. 12, pp. 205-231 (in Turkish).

15. Failler A. (ed.). Georges Pachymérès. Relations historiques, vols. 1-5. Paris, Les Belles Lettres Publ., 19842000 (in Greek and in French).

16. Giannopoulos N. I. The Monastery of St. Laurentius on Mt. Pelion. Epistēmonikē Epetēris Byzantinon Spoudon, 1935, vol.11, pp. 385-408 (in Greek).

17. Gioles N. Byzantine Naodomia (Byzantine Church Architecture). Athens, Kardamitsas Publ., 1987. 240 p. (in Greek).

18. Grabar A. Sculptures byzantines du Moyen Age, II (XIe-XIVe siècles). Paris, Picard Publ., 1976. 167 p. (in French).

19. Grozdanov C. Prilozi proučavanju Sv. Sofije ohridske u XIV veku. Zbornik za likovne umetnosti, 1969, vol. 5, pp. 49-63 (in Serbian).

20. Kafadar C. Introduction: A Rome of One's Own: Reflections on Cultural Geography and Identity in the Lands of Rum. Muqarnas, 2007, vol.24, pp.7-25.

21. Karagianni F. A. Episkopikoi naoi tēs mesis Byzantinis periodou, To paradeigma tēs Makedonias, Ph. D. Thesis. Thessaloniki, 2006 (in Greek).

22. Karpologou A. Notes on Veria. Makedonikon Hemerologion, 1911, vol. 4, pp. 278-284 (in Greek).

23. Koumanoudis I. N. Additional Research on the Christian Monuments of Oropos. Deltion tēs Christianikēs Archaiologikēs Etaireias, 1969, vol. 5, pp. 57-104 (in Greek).

24. Lampakis G. Mémoire sur les antiquités chrétiennes de la Grèce, présenté au Congrès international d' histoire comparée, Paris, 1900. Athènes, Imprimerie 'Hestia' Publ., 1902. 94 p. (in French).

25. Laurent V. Une famille turque au service de Byzance. Les Melikes. Byzantinische Zeitschrift, 1956, vol.49, pp. 349-368 (in French).

26. Leonidopoulou-Stylianou R. Remarks on the Monastery of St. Lavrentius on Pelion. Deltion tēs Christianikēs Archaiologikēs Etaireias, 1977-1979, vol.9, pp. 223-248 (in Greek).

27. Macridy T. The Monastery of Lips and the Burials of the Palaeologi. Dumbarton Oaks Papers, 1964, vol. 18, pp. 253-277.

28. Makaronas Ch. I. Archaeological Chronicles. Makedonika, 1941-52, vol. 2, pp. 590-678 (in Greek).

29. Marangoz E. B. Konya ve merkez ilçelerindeki (Karatay, Meram, Selçuklu) Anadolu Selçuklu Dönemi sütun ve sütunçe başlıkları, Post Graduate Thesis. Istanbul University, Institute of Social Sciences, 2019. (in Turkish)

30. Matsou A. Hē architektoniki kai ta glypta tēs monēs tou Aghiou Lavrentiou sto Pēlio. University of Thessaly, 2016. 30 p. (in Greek).

31. Melikis G. Ta laographika tēs Melikis, D', vol.4. Thessaloniki, Laographikos Omēlos Melikis kai perichoron Publ., 1987. 219 p. (in Greek).

32. Melvani N. Late Byzantine Sculpture, Studies in the Visual Cultures of the Middle Ages 6. Turnhout, Brepols Publ., 2013. 299 p.

33. Millet G. L' ancien art serbe. Les églises. Paris, E. de Boccard Publ., 1919. 208 p. (in French).

34. Moschopoulos G. D. Roumloukiotika sēmeiomata 1980-1988. Thessaloniki, University Studio Press Publ., 1989.93 p. (in Greek).

35. Mylonas P. Notes on the Chelandari Catholic Church. Archaiologia, 1985, vol. 14, pp. 64-83 (in Greek).

36. Nelson R.S. Palaeologan Illuminated Ornament and the Arabesque. Wiener Jahrbuch für Kunstgeschichte, 1988, vol.41, pp.7-22, 151-162.

37. Nelson R.S. Tales of Two Cities: The Patronage of Early Palaeologan Art and Architecture in Constantinople and Thessaloniki. Manuel Panselinos and His Age. Athens, The National Hellenic Research Foundation Publ., 1999, pp. 127-145.

38. Nenadović S. Larchitecture des églises du monastère Chilandar. Recueil de Chilandar, 3. Beograd, Académie Serbe des sciences et des arts Publ., 1974, pp. 85-208 (in French).

39. Orlandos A. Ho The Taxiarchis of Lokris. Epēstēmoniki Epetēris Byzantinon Spoudon, 1929, vol. 6, pp. 355368 (in Greek).

40. Orlandos A. Porta Panaghia of Thessaly. Archeion Byzantinon Mnēmeion Ellados, 1935, vol. 1, pp. 5-40 (in Greek).

41. Özkul K. Sivas Divriği Ulu Mosque and Darüşsifa Decorations. International Journal of Volga-Ural and Turkestan Studies, 2020, vol. 2, no. 3, pp. 56-81. 
42. Özkul K. Sivas Divriği Ulu Mosque and Darüşşifası Taç Doors; Darüşşifası Door. Mobo F. D.; Khadharaoui Ontunc S. (eds.). $4^{\text {th }}$ Asia Pacific International Modern Sciences Congress. Subic Bay Freeport Zone, College of Subic Montessori Publ., 2020, pp. 116-128.

43. Papazotos Th. The Founder's Inscription of the Old Metropolis in Veria. Istorikogeographika, 1986, vol. 1, p. 200 (in Greek).

44. Papazotos Th. Hē Veria kai oi naoi tēs (11os - 18os ai.), Historiki kai archaiologiki spoudi ton mnèmeion tēs polēs. Athens, Tameio Archaiologikon Poron kai Apallotrioseon Publ., 1994. 347 p. (in Greek).

45. Pazaras Th. Reliefs of a Sculpture Workshop Operating in Thessaly and Macedonia at the End of the $13^{\text {th }}$ and Beginning of the $14^{\text {th }}$ Century. L' art de Thessalonique et des pays balkaniques et les courants spirituels au XlVe siècle, Recueil des rapports du IVe Colloque serbo-grec, Belgrade 1985. Belgrade, Académie serbe des sciences et des arts Publ., 1987, pp.159-182.

46. Pazaras Th. Anaglyphes sarcophagoi kai epitafies plakes tēs mesis kai hysteris byzantinis periodou stēn Ellada. Athens, Tameio Archaiologikon Poron kai Apallotrioseon Publ., 1988. 190 p. (in Greek).

47. Pazaras Th. A Proposal for the Ambo Reconstruction of the Old Cathedral in Beroia. Thymiama stē mnēme tēs Laskarinas Boura. Athens, Benaki Museum Publ., 1994, vol. 1, pp. 251-254, vol. 2, pl. 136-147 (in Greek).

48. Petrov K. Dekorativna plastika na spomenitse od XIV vek vo Makedonia. Godišen Zbornik, 1963, vol. 15, pp. 199-286 (in Macedonian).

49. Savvidès A. G. Note on the Terms Rum and Anatolia during the Seljukid and Early Ottoman Period. Deltio Kentrou Mikrasiatikon Spoudon, 1984, vol. 5, pp.95-102 (in Greek).

50. Schinas N. Odoiporikai Sēmeioseis Makedonias, Ëpeirou, Neas Orothetikis Grammis kai Thessalias, vol. 1-2. Athens, Messager s'Athènes Publ., 1886. 488 p. (in Greek).

51. Shukurov R. The Oriental Margins of the Byzantine World: A Prosopographical Perspective. Herrin J.; SaintGuillain G. (eds.). Identities and Allegiances in the Eastern Mediterranean after 1204. Aldershot, Routledge Publ., 2011, pp. 167-194.

52. Shukurov R. The Byzantine Turks 1204-1261 (The Medieval Mediterranean 105). Leiden; Boston, Brill Publ., 2016. $513 \mathrm{p}$.

53. Skiadaresis G. Hē Palaia Mètropolè tēs Verias sto plaisio tēs Byzantinis Architektonikis, Ph. D. Thesis. Thessaloniki, 2016. 304 p. (in Greek).

54. Skiadaresis G. The Church of Old Metropolis of Veria in the First Ottoman Centuries. Myrionymon Efhos, vol. C', Veria, 2019, pp. 537-550 (in Greek).

55. Sotēriou G. Byzantine Monuments of Thessaly from the Thirteenth and Fourteenth Centuries. 2. The monastery of Panaghia and St. Demetrios at Tsagezi. Epēstimoniki Epetēris Byzantinon Spoudon, 1928, vol. 5, pp. 348-375 (in Greek).

56. Sotēriou G. A. Byzantine Basilikas of Macedonia and Old Greece. Byzantinische Zeitschrift, 1929, vol.30, pp. 568-576 (in Greek).

57. Sotēriou M. Arabic Decorations on the Byzantine Monuments of Greece. Deltion tēs Christianikēs archaiologikēs Etaireias, 1933, vol.2, pp. 57-93 (in Greek).

58. Struck A. Makedonische Fahrten. II. Die makedonischen Niederlande. Zur Kunde der Balkanhalbinsel. Vienna; Leipzig, A. Hartleben Publ., 1907. 99 p. (in German).

59. Sythiakaki-Kritsimallē V. Recent Remarks on the Marble Templon of Taxiarchis in Lokris. Deltion tēs Christianikēs Archaiologikēs Etaireias, 2006, vol.28, pp. 125-136 (in Greek).

60. Theocharidis G.I. A Byzantine Will and a Trial, Unpublished documents from Vatopedi Monastery on Mt Athos. Makedonika, Parartèma 2. Thessaloniki, Society for Macedonian Studies Publ., 1962 (in Greek). 96 p.

61. Trapp E.; Walther R.; Beyer H.V. (eds.). Prosopographisches Lexikon der Palaiologenzeit, 1-12. Vienna, Verlag der Österreichischen Akademie der Wissenschaften Publ., 1976-1996. Available at: http://austriaca. at/3310-3inhalt (accessed 17 August 2021).

62. Van Dieten J.L. (ed.). Nikephoros Gregoras. Rhomäische Geschichte, vols. 1-6. Stuttgart, Hiersemann Publ., 1973-2007 (in German).

63. Velenis G. Ermèneia tou eksoterikou diakosmou stē byzantinē architektonikē, apo ton 10 o aiona os tēn kataktise tēs periochis apo tous Tourkous, Ph.D. Dissertation. Thessaloniki, 1984. 320 p. (in Greek).

64. Velenis G.M. Hē architektonikē scholē tēs Makedonias kata tē mesē kai ysterē byzantinē periodo. Synaxi, 1997, vol.63, pp. 49-59 (in Greek).

65. Wittek P. La descendance chrétienne de la dynastie Seldjouk en Macédoine. Échos d' Orient, 1952, vol. 176, pp. 409-412 (in French). 
66. Xyngopoulos A. The Cover of George Kapandritis' Sarcophagus. Epetires Etaireias Byzantinon Spoudon, 1935, vol. 11, pp. 346-360 (in Greek).

67. Zachariadou E. The Christian Descendants of Izzedin Kaikaus B' in Veria. Makedonika, 1964-1965, vol. 6, pp. 62-74 (in Greek).

Title. Palaeologan Veria: A Peripheral Center under the Perspective of Its Monuments. The Case of the Marble Decoration from the Old Metropolitan Cathedral as a Possible Donation by Christian Members of the Seljuk Dynasty

Author. Cheimonopoulou, Maria V. - Ph. D., head of the Department of Byzantine and Post-byzantine Antiquities and Museums. Hellenic Ministry of Culture and Sports, Ephorate of Antiquities of Imathia, Riga Fereou 16-18, 59132 Veria, Greece. cheimaria@yahoo.gr ORCID: 0000-0001-8010-7657

Abstract. By the rising of the Palaiologan dynasty in Constantinople, regional centers on the Greek mainland, such as Veria, lived and prospered under the influence of the Byzantine capital, and at the same time geographically close Thessaloniki. The essay presents sculptures that came to light during the first phase of the investigations and the main phase of restoration of the Old Metropolis in Veria during the years 2011-2015. The sculptures decorated with arabesque motifs form a group with common stylistic features and are associated with a phase of renewal of the church's liturgical furnishings in the first two decades of the $14^{\text {th }}$ century, when the ecclesiastical seat of Veria was raised from an Archdiocese to a Metropolitan seat. The subject matter of the sculptures, although widespread in the Palaiologan era as the result of the interaction of the Christian with the Islamic world, might be associated with the presence, documented by written sources, of the family of Sultan 'Izz ad-Din Kaykaus II in Veria. The study of the documents, sources and published material and assessment of the evidence relating to members of the Seljuk ruling house of Iconium who settled in Byzantine territories of Imathia, the region of Veria including the village of Komanitzes, and the areas of Meliki, Ressiane, and Nese, reveals three noble families who took over the lands and general administration during the Palaiologan era. Since it is known from the archival researches of E. Gara that the Old Metropolis of Veria and its environs were known in the late $16^{\text {th }}$ and early $17^{\text {th }}$ century as the Melek Monastery, we think it is probable that the architectural sculptures described above were given to the church by that family, who could have been its patrons and benefactors.

Keywords: Veria, Seljuks, Old Metropolis, sculptures, arabesque motifs, Palaeologan period

Название статьи. Палеологовская Верия, провинциальный центр и его памятники. Мраморный декор Старой митрополии как возможный заказ христианских представителей сельджукской династии

Сведения об авторе. Мария В. Химонопулу - Ph. D., заведующая отделом византийских и поствизантийских памятников и музеев. Греческое министерство культуры и спорта, Инспекция древностей Имафии, ул. Рига Фереу 16-18, 59132 Верия, Греция. cheimaria@yahoo.gr ORCID: 0000-0001-8010-7657

Аннотация. С воцарением династии Палеологов в Константинополе региональные центры в Греции, такие как Верия, жили и процветали, испытывая влияние византийской столицы и в то же время географически близкой Фессалоники. В статье представлены элементы скульптурного декора, обнаруженные на первом этапе исследований во время реставрационных работ в Старой митрополии в 20112015 гг. Мраморные детали, украшенные мотивами арабесок, составляют группу со схожими стилистическими чертами и связанную с обновлением убранства храма в первые два десятилетия XIV в., когда Верия приобрела статус митрополии. Эти мотивы мраморной резьбы являются широко распространёнными в палеологовскую эпоху и представляют собой результат взаимодействия христианской и мусульманской традиции. Они могут быть связаны с присутствием в Верии членов семьи султана Изз ад-Дина Кей-Кавуса II, подтверждённым письменными источниками. Анализ источников и опубликованных материалов, связанных с родственниками правителей Иконийского султаната, поселившимися на территории византийской Имафии, показывает, что в окрестностях Верии и близлежащих деревень Команицес, Мелики, Рессиани и Ниси в палеологовский период проживали три знатные семьи, управлявшие этими территориями. Поскольку благодаря архивным исследованиям известно, что Старая митроплия в Верии и квартал вокруг неё в XVI-XVII вв. назывались «монастырь Мелик», мы предполагаем, что скульптурный декор храма, описанный в статье, был пожертвован в храм представителями этих семей, которые могли выступить в роли ктиторов и благотворителей.

Ключевые слова: Верия, сельджуки, Старая митрополия, скульптурный декор, арабески, палеологовский период 

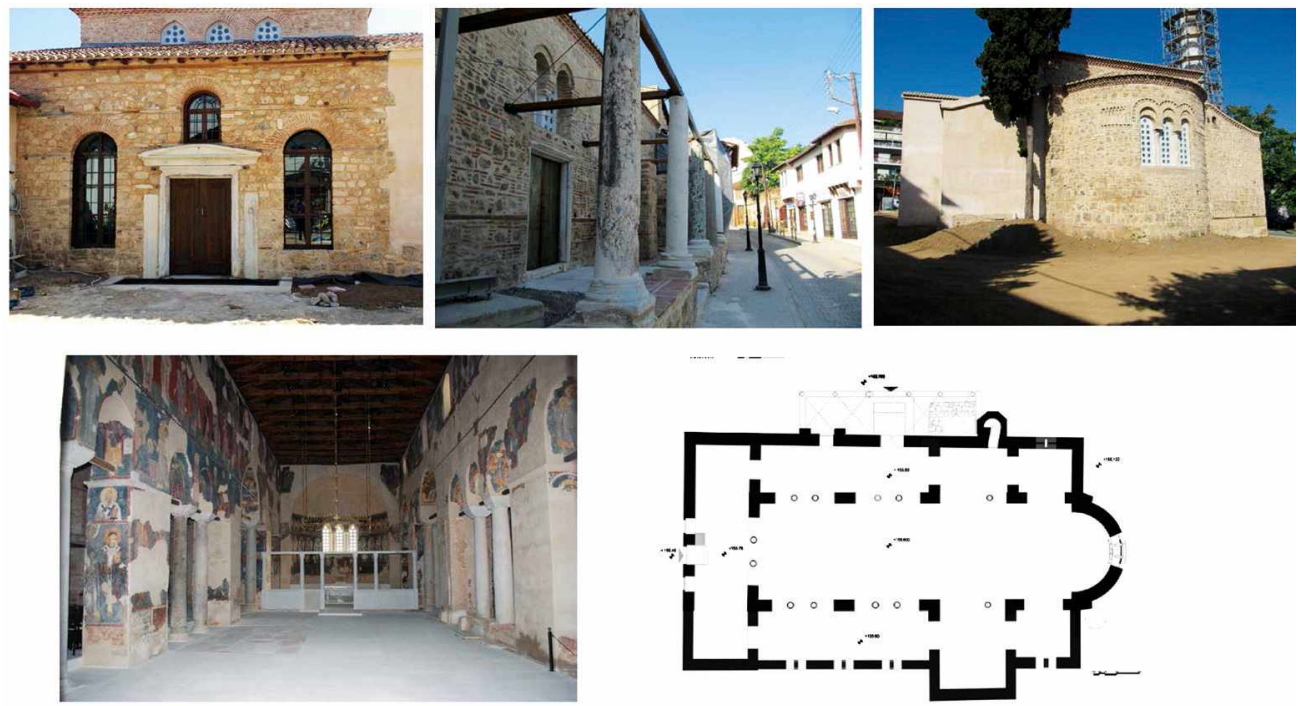

Ill. 32. Veria, Old Metropolitan Cathedral. Hellenic Ministry of Culture and Sports, Photographic Archive of the Ephorate of Antiquities of Imathia
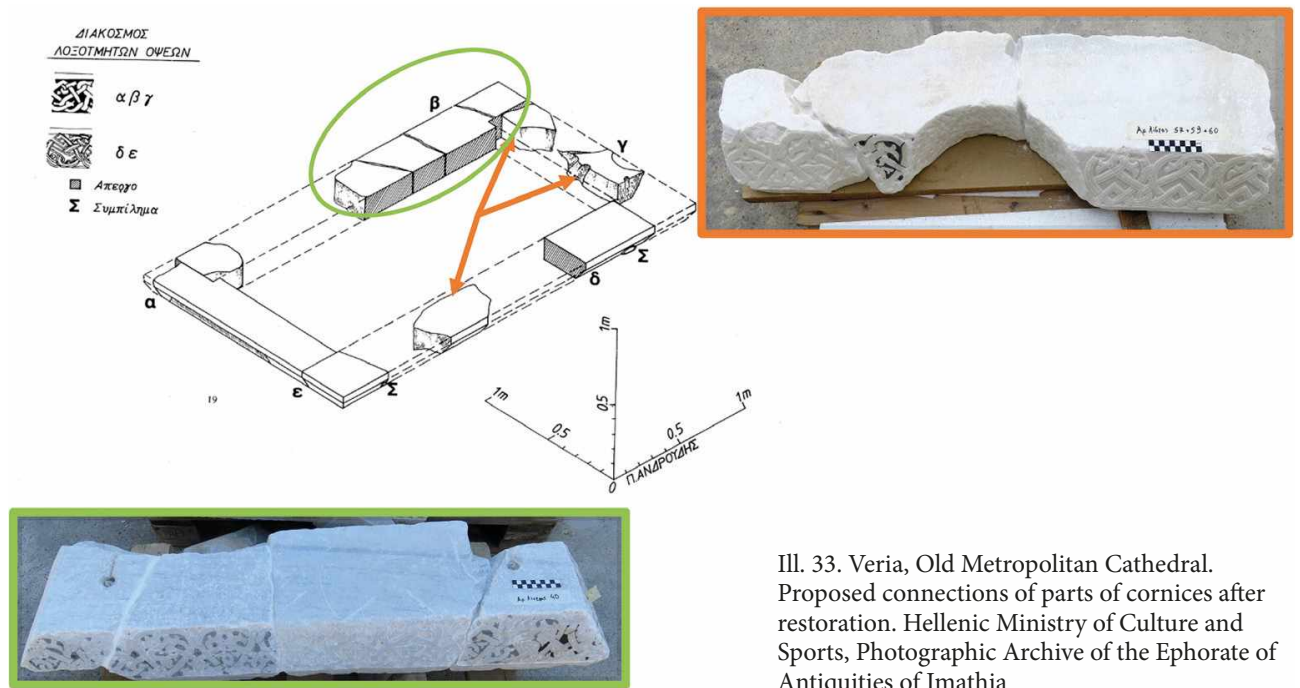

Ill. 33. Veria, Old Metropolitan Cathedral. Proposed connections of parts of cornices after restoration. Hellenic Ministry of Culture and Sports, Photographic Archive of the Ephorate of Antiquities of Imathia 


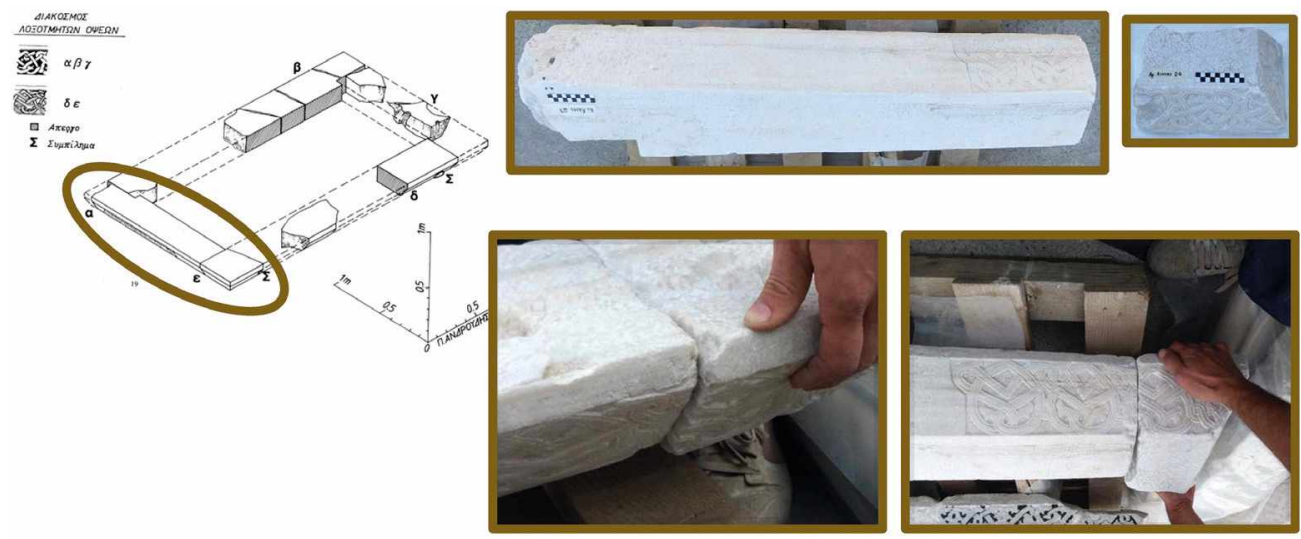

Ill. 34. Veria, Old Metropolitan Cathedral. Parts of cornice(s) probably not joined together in the Palaeologan phase. Hellenic Ministry of Culture and Sports, Photographic Archive of the Ephorate of Antiquities of Imathia
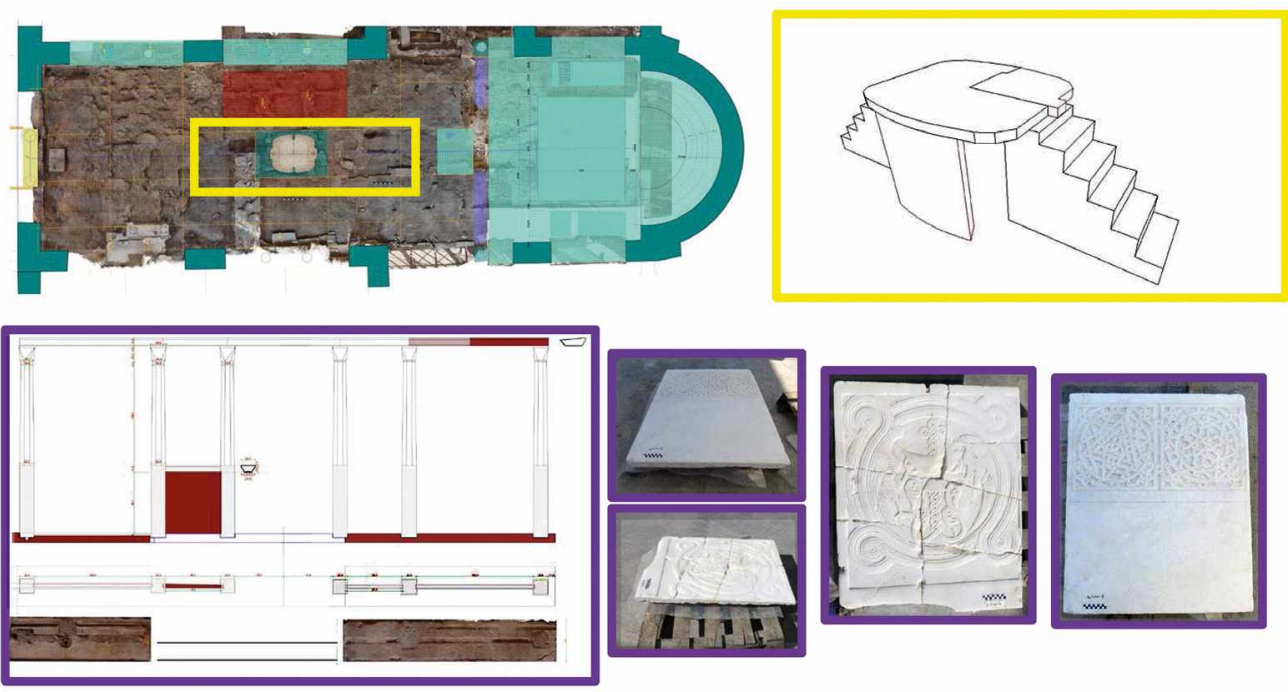

Ill. 35. Veria, Old Metropolitan Cathedral. Excavated locations of the church's pulpit and templon barrier. Hellenic Ministry of Culture and Sports, Photographic Archive of the Ephorate of Antiquities of Imathia 